\title{
A LETRA E A VOZ EM TRÊS ROMANCES DO GRAAL
}

Demétrio Alves Paz ${ }^{1}$

\section{RESUMO}

O presente ensaio tem por objetivo analisar o narrador e os personagens em três romances de cavalaria que tratam do Graal: Perceval, de Chrétien de Troyes; Parsifal, de Wolfram von Eschenbach e A Demanda do Santo Graal, texto anônimo português. Após a análise do contexto de produção das obras, utilizam-se as ideias de Paul Zumthor e de Walter Benjamim a respeito da relação entre oralidade e escrita para comentar o narrador presente nos romances. Depois, investigam-se os personagens de acordo com a tipologia proposta por Antonio Prieto. Os dois primeiros romances que tratam do Graal estão mais próximos não só da oralidade como também do mito, ao passo que no texto português há um controle maior da narração devido ao seu caráter religioso.

Palavras-chave: Narrador. Personagem. Oralidade. Idade Média. Graal.

\section{THE WRITING AND THE VOICE IN THREE GRAIL NOVELS}

\begin{abstract}
The objetive of this paper is to analyse the narrator and the characters in the romances of chivalry about the Grail: Perceval, by Chrétien de Troyes; Parsifal, by Wolfram von Eschenbach and $A$ Demanda do Santo Graal, an anonymous portuguese text. After analysing the prodution context of these works, it is used the ideas of Paul Zumthor and Walter Benjamim about the relation of orality and writing to discuss the narrator of the novels. Then, the characters are investigated according to the typology proposed by Antonio Prieto. The first two romances of chivalry about
\end{abstract}


the Grail are closer not only to the orality as well as the myth, whereas in the portuguese text there is a greater control of the narrative due to its religious characteristic.

Key-words: Narrator. Character. Orality. Middle Ages. Grail.

\section{INTRODUÇÃO: A CANÇÃO DE GESTA, A LÍRICA TROVADORESCA E OS ROMANCES DE CAVALARIA}

Na Idade Média havia dois tipos de cultura: a erudita ou clerical e a profana ou laica. A primeira era produzida pelo clero na língua oficial da Igreja, o Latim; a segunda era falada e, às vezes, escrita pelo povo na sua língua, isto é, nas línguas românicas ou vulgares, que ainda estavam em formação. (FERREIRA, 1988; AUERBACH, 1989) No século XII, surgiram as duas grandes produções literárias laicas da Idade Média: a lírica trovadoresca e o romance de cavalaria. Segundo Auerbach (1989), a lírica trovadoresca e o romance cortês foram as primeiras escolas literárias do Ocidente, cujas produções foram concebidas em língua vulgar. Em diversos países da Europa eram escritos textos em provençal, a língua literária do século XII. Auerbach (1989) concebe como escola literária a língua em que as obras foram escritas e as semelhanças estilísticas adotadas por diferentes autores em diferentes países.

Tanto na lírica quanto nos romances, a mulher quase sempre ocupa um papel destacado. Tudo que o trovador ou o cavaleiro faz é em nome dela. A lírica teve como principal incentivadora Eleonor da Aquitânia, neta de Guilherme de Poitiers, o primeiro trovador provençal. Ela foi uma mulher à frente de sua época, incentivadora das artes. Seus filhos e netos, que foram os governantes da Europa dos séculos XII e XIII, herdaram da grande matriarca o gosto artístico. (DUBY, 2013) O romance de cavalaria surgiu na França, sendo sinônimo do romance cortês. Chrétien de Troyes é o criador do romance cortês com suas obras tendo como personagens principais Enéias, em Romance de Tebas e Alexandre, em Romance de Alexandre. O metro alexandrino (doze sílabas poéticas) tem o nome devido ao metro criado pela escrito francês. No mesmo estilo do romance cortês, Chrétien começou a escrever sobre os cavaleiros do rei Artur, motivo pelo qual essas obras ficaram conhecidas pelo nome 
de romances de cavalaria. Vale lembrar que ambos eram escritos em versos, somente a novela de cavalaria, surgida no século XIII, seria escrita em prosa. Da França, o romance de cavalaria espalhou-se por toda a Europa.

Para Auerbach (1989), a matéria principal desse tipo de romance é a vida luxuosa de uma sociedade elegante, com hábitos cuidadosamente estabelecidos, conhecidos como cortesia. Danielle Régnier-Bohler (2002, p. 48) define cortesia como "o ideal do comportamento aristocrático, uma arte de viver que implica polidez, refinamento de costumes, elegância, e ainda, além dessas qualidades puramente sociais, o sentido da honra cavaleirosa". Tudo isso foi idealizado e transposto para o imaginário bretão que tinha um rei lendário: Artur. A essa lenda foi acrescentada uma corte, a Távola Redonda, seus cavaleiros e, obviamente, suas aventuras. Auerbach (1989, p. 116) nos diz que "A corte do Rei Artur tornou-se o ideal da sociedade polida". Na França do século XII, essa sociedade educada é, predominantemente, representada pelo romance cortês no norte e pela lírica trovadoresca no sul.

Por que Artur é o modelo de rei nesse tipo de romance? O que ele tinha de especial? Artur representava um passado histórico e heróico. Ele teria sido um guerreiro bretão que conteve a invasão anglo-saxã na Inglaterra do século VI. O rei bretão seria um bom modelo de conduta a ser imitado pela sociedade, representando os seus ideais e configurando o imaginário social que, tal como nos propõe Hilário Franco Júnior (1998, p. 277), "reúne experiências inconscientes do passado longínquo e subconscientes de um tempo mais recente". No caso de Artur, a lenda apresenta uma roupagem moderna (séc.XII) de um passado distante (séc.VI). Não nos esqueçamos de que Artur e seus cavalheiros, que teriam vivido no século VI, agiam como se estivessem no século XII, a época em que esses romances foram produzidos.

Essa literatura era feita sobre e para a corte, visto que "numa sociedade o imaginário tem seguramente tanta importância e eficácia quanto as condições reais da vida e do pensamento" (LE GOFF, 2013, p. 11). Assim, esses textos atenderiam aos desejos e anseios da sociedade que se queria representada, sendo os nobres e seus subordinados os receptores. Podemos notar um caráter didático nos romances em relação aos costumes e aos comportamentos da nobreza nessa representação surgida do imaginário bretão, baseado nas lendas arturianas. Sabemos que a cavalaria era brutal e selvagem, porém, a literatura, que a representa, não mostra essa face da instituição. Ao se apropriar desse tema, a literatura confirma que a 
ficção é "escrita e lida para prover seres humanos com vidas que eles não se resignavam em não ter" (LLOSA, 1984).

Nos séculos XII e XIII, o latim era a língua oficial da lgreja, mas não era a falada pela maior parte da população ocidental. A grande maioria da população falava o vulgo, o dialeto de sua região. Foi nessa língua vulgar que surgiram as obras literárias de que trataremos a seguir, assim como é por essa natureza linguística que elas puderam proliferar por toda a Europa.

A literatura medieval era destinada à récita. Em primeiro lugar, porque poucos eram os que sabiam ler e menos ainda os que sabiam escrever, mesmo dentro da Igreja. Em segundo, porque a escrita e a récita eram o ofício de algumas pessoas, preparadas para essa função, principalmente os jograis, menestréis e trovadores. Paul Zumthor (2001, p. 21) prefere o uso da palavra vocalidade ao invés de oralidade, pois aquela "é a historicidade de uma voz: seu uso". O uso dessa voz deu-se, sobretudo, com o verso, que foi o principal meio de propagação da literatura durante a Idade Média. Nessa forma, foram recitadas e, depois, escritas as canções de gesta e a lírica provençal. Contudo, devemos salientar que o romance de cavalaria está ligado ao surgimento da escrita. De acordo com Robert Scholes e Robert Kellogg (1977, p. 36-37),

\footnotetext{
os maiores "romances" medievais não foram compostos oralmente, embora dependessem fortemente de elementos tradicionais, alguns dos quais podem, inclusive, ter sido extraídos diretamente da tradição oral ou de versões transcritas de narrativas orais. Os "romances" associados aos nomes de Chrétien de Troyes, Wolfram von Eschenbach e Gottfried von Strassburg devem, provavelmente, ser atribuídos aos gênios criativos desses indivíduos.
}

O romance de cavalaria não surgiu ex-abrupto, ele possui uma história ligada a outros gêneros, principalmente à canção de gesta e à lírica trovadoresca provençal. Consideramos que ele é tributário da canção de gesta pelo seu gosto pela aventura, pela guerra, pelos feitos heroicos, assim como é devedor da lírica trovadoresca pelo culto à mulher e ao amor, pelo menos em sua origem com Chrétien de Troyes. No século XIII, o romance cortês cristianiza-se e torna-se místico-religioso, tal como vêse na Demanda do Santo Graal.

Quando a canção de gesta perde a sua força e a lírica provençal começa a espalhar-se por toda a Europa na metade do século XII, o romance de cavalaria surge no norte. Romance cortês, como ele também é conhecido trata de uma corte 
ideal. Como Duby (1998, p. 158) nos informa:

\begin{abstract}
São as grandes cortes que dão o tom, ditando as modas, mostrando como devem se comportar as pessoas bem-nascidas se querem ser dignas de sua categoria. Essas cortes foram, de início, as que reuniam os príncipes feudais rivais dos Capetos, Henrique Plantageneta, e conde da Flandres, o conde da Champagne, que viam precisamente, no brilho da cultura produzida e codificada em torno de suas pessoas, um meio bastante seguro de elevar o próprio prestígio face ao do rei.
\end{abstract}

Essas cortes do norte, ao assimilarem alguns costumes das cortes do sul, tornaram-se mais refinadas. Os primeiros romances corteses tratavam da Antiguidade greco-latina, seus heróis eram Alexandre e Enéias, e as cidades eram Tróia e Tebas. Apesar do prestígio que os heróis da Antiguidade gozavam, foram outros o herói e a cidade dos romances corteses: Artur e Camelote.

Como qualquer outro escritor medieval, principalmente de sua época, não se sabe muito a respeito de Chrétien de Troyes. Nasceu, provavelmente, em Troyes em 1134, teve uma boa educação, pois conhecia Ovídio e foi seu tradutor. Dentre as várias obras que teria escrito, só são conhecidas seis obras dele. Guilherme de Inglaterra, obra da juventude, é inspirada na lenda de santo Eustáquio. Os outros cinco romances são os primeiros a tratar do rei Artur e de seus cavaleiros: Eric e Enide; Cliges, ou a que fingiu de morta; Lancelote, o cavaleiro da carreta; Ivain, o cavaleiro do Leão, e Perceval ou o romance do Graal. A última é uma obra inacabada devido à morte do autor, mas que teve várias continuações por diferentes escritores.

O talento de Chrétien é indiscutível e atestado por diversos críticos, entre eles Erich Auerbach (1989; 2002), Arnold Hauser (2000), Manuel Rodrigues Lapa (1966), Segismundo Spina (1997). Também é ele o escritor responsável pelo caráter místico do Graal, além de ter sido o primeiro a ligá-lo ao rei Artur e seus cavaleiros. O autor foi menestrel nas duas grandes cortes francesas de seu tempo: a de Champagne e a de Flandres. Maria, filha de Eleonor, casou-se com Henrique I da Champagne e transformou sua corte num centro de cultura. Foi nesse ambiente cultural que Chrétien escreveu Lancelote. Sob a proteção de Filipe de Flandres, um grande incentivador das artes, o menestrel francês iniciou o seu Perceval. Supõe-se que o primeiro Tristão e Isolda tenha sido escrito por ele, mas nunca foi encontrada uma cópia dessa obra, porém no início de Cliges, ou a que fingiu de morta, Chrétien nomeia as suas obras e entre elas está "O rei Marc e Isolda, a Loura" (TROYES, 
1998, p. 77).

No romance cortês, só pode haver um herói. Não é permitido que outra personagem tenha mais importância que ele, sendo quase sempre o título da obra o nome dessa personagem. Apesar disso, o nome de Gawain ou Galvão aparece sempre em segundo lugar. Por um lado, é curioso o fato de Chrétien e outros autores do século XII e início do XIII não terem escrito um romance sobre ele, pois é uma das principais personagens da tradição arturiana na Inglaterra. Gawain ou Galvão é sobrinho do rei Artur, excelente cavaleiro e muito cortês. Por outro lado, ele é a única das personagens a estar presente em todas as obras do escritor francês e em todos os romances escritos que tratam do rei Artur e de seus cavaleiros. Na Demanda portuguesa e na Queste del Saint Graal francesa, Galvão é transformado no cavaleiro traidor e mau, muito diferente do modo como aparecia nos romances anteriores. Somente no século XIV ele aparecerá como personagem principal de uma obra: Sir Gawain e o Cavaleiro Verde.

Seguindo a mesma linha de Chrétien, Wolfram von Eschenbach escreve Parsifal, obra em que o Graal recebe um tratamento diferenciado daquele dado por seu antecessor. Tanto o herói, Parsifal, como a estrutura narrativa são muito superiores ao texto homônimo francês. No romance alemão, o Graal é uma pedra e seu herói deve passar por um longo aprendizado para tornar-se apto a ser rei do Graal. Vários críticos, entre eles Otto Maria Carpeaux (1994) e Arnold Hauser (2000), consideram Wolfram von Eschenbach o maior poeta épico medieval alemão, assim como a obra Parsifal o primeiro romance de formação da literatura europeia, entendido aqui como o romance "que trata do desenvolvimento de uma personagem, da infância à maturidade". (CORP, 2001, p. 425)

O texto português Demanda do Santo Graal seria uma tradução da Quest del Saint Graal, texto francês do século XII. Na Demanda, é narrada a procura do Santo Graal e um novo personagem é acrescentado a narrativa: Galaaz, filho de Lancelote e Elaine, princesa do castelo do Graal. Galaaz faz parte da cavalaria celeste, por isso ele toma o lugar que antes pertencia a Perceval. Existem duas hipóteses a respeito da escritura da Demanda portuguesa. (MEGALE, 1992; LAPA, 1966) Na primeira, o texto português seria a tradução de um original francês perdido. $\mathrm{Na}$ segunda, que é a mais provável e aceita entre os estudiosos do texto, a narrativa é a compilação de três obras: José de Arimatéia, Quest del Saint Graal e Morte do rei Artur. Elas teriam chegado até Portugal, trazidas por alguém, provavelmente um 
monge cisterciense, que foi o compilador das histórias. A Demanda portuguesa é o maior corpus literário da pós-Vulgata conhecido na Europa atualmente. Uma cópia do manuscrito, a única conhecida, foi encontrada no século XIX, é o manuscrito número 2594 da Biblioteca Nacional de Viena.

Segundo Lapa (1966), há duas teorias para a origem do ciclo arturiano. A primeira é de que esse ciclo teria origens célticas. Ela é defendida por Gaston Paris e Jean Marx. A segunda atribuiria ao ciclo uma origem francesa, tendo como defensor dessa tese o alemão Wendelin Foerster. Dois estudiosos, Roger Sherman Loomis e Ferdinand Lot, reconhecem que é o amálgama das duas tradições que possibilitou o surgimento desse ciclo. Concordamos também com esse amálgama de tradições, pois sabemos que havia um grande intercâmbio cultural de jograis, menestréis e trovadores entre as cortes inglesas e francesas da época, principalmente porque os Plantagenetas eram senhores nos dois lados do Canal da Mancha.

No século XII, as obras circularam e divulgaram-se graças aos jograis e ao aparecimento do livro manuscrito de circulação dentro das grandes cortes europeias. Philippe Willemart (2000, p. 17) assim define o jogral:

\begin{abstract}
Diferente do menestrel ligado a uma corte determinada, era um homem livre, vilão, independente que cantava nas feiras, peregrinações e nas praças públicas. Ele vivia de sua profissão aprendida às vezes na escola latina do claustro ou do capítulo da catedral. [...]

Tivesse a possibilidade, o jogral seguira um curso especializado em língua vulgar como o da escola de Beauvais, onde aprenderia algumas técnicas de versificação, aperfeiçoava sua dicção, seu canto e sua mímica. Em seguida, podia comprar um repertório dum outro jogral que ele copiava e completava e assim iniciava a profissão. Se ele inventava ou achava (trouver - trovar), se tornava trovador.
\end{abstract}

Dessa forma, percebemos que a diferença entre menestrel e jogral é pequena. O jogral é um ambulante, divulgando o seu trabalho e o de outros pelas cortes; o menestrel trabalha numa corte específica. O trovador é o grande compositor, com repertório e temas originais.

Maria da Conceição Vilhena (1990, p. 55-56) aponta como surgiu o livro manuscrito e de que forma ele espalhou-se pelas cortes:

Até o séc. $\mathrm{XI}$, o livro era resultado de um trabalho lento e meticuloso feito apenas por religiosos, que os copiavam e enfeitavam de iluminuras, com tanto zelo como se se destinassem a ser utilizados pelo próprio Deus. Eram feitos nos mosteiros e a eles se destinavam, nunca saído de suas 
bibliotecas, pois só aos que aí professavam cabia então o monopólio do saber.

A partir desta data, porém, a preocupação estética passa para segundo plano. É que o livro começa a ser feito por copistas assalariados, mais rápidos e menos meticulosos, que usam as abreviaturas e suprimem grande parte da ornamentação. A produção aumenta e surgem, desse modo, no início do séc. XII, as primeiras livrarias, onde o livro pode ser adquirido, a troco de dinheiro. Esta evolução teve um alcance enorme não só na divulgação da cultura laica, mas também na difusão das ideias e, consequentemente, no incremento da discussão e no desenvolvimento do espírito crítico ou contestatário.

Podemos perceber que tanto a lírica trovadoresca, quanto a canção de gesta e o romance de cavalaria tiveram nos manuscritos um grande aliado na sua difusão, tornando-o acessível e de fácil circulação por toda a Europa, como atestam as diferentes cópias encontradas em diferentes países. (LAPA, 1966; SPINA, 1997) Esse fato comprova, igualmente, a popularidade que essas obras possuíam na sua época.

\section{O NARRADOR: POPULAR OU ERUDITO CONTROLADOR}

Nos três romances aqui estudados, temos dois autores expressamente nomeados, Chrétien de Troyes e Wolfram von Eschenbach, e um anônimo, o da Demanda. Contudo, há um aspecto irônico e quase contraditório: esse romance anônimo não possui o perfil do narrador popular, o qual Walter Benjamin (2010) considera o narrador ideal. De acordo com o crítico alemão, "entre as narrativas escritas, as melhores são as que menos se distinguem das histórias orais contadas pelos inúmeros narradores anônimos" (BENJAMIM, 2010, p. 198). Por que isso acontece?

O narrador de Parsifal, e está-se a falar de Wolfram Von Eschenbach, pois não havia divisão naquela época entre o autor e o narrador, é aquele proposto por Walter Benjamin, uma vez que a sua narrativa tem "uma dimensão utilitária" (BENJAMIM, 2010, p. 200). Qual seria a sua utilidade? Wolfram (1995, p. 29), logo no início da narração, diz: "Ora, não conheço qualquer pessoa inteligente que não quisesse alcançar o sentido mais profundo desta história e os ensinamentos que ela oferece". Além disso, ele pretende contar "uma história que trata da lealdade inquebrantável e da verdadeira essência do homem" (ESCHENBACH, 1995, p.30), pois "só aos poucos adquiriu verdadeira experiência" (ESCHENBACH, 1995, p. 30). Desse modo, chega-se ao que Carpeaux (1978) disse sobre o romance de formação, ou seja, 
aquele que responde às necessidades do homem, cuja essência reside na busca do conhecimento pela experiência, aprendizado e sabedoria, o que só se adquire gradualmente. Por isso a viagem nos romances do Graal torna-se necessária: o jovem deve conhecer o mundo para poder transformar-se em indivíduo. Nesse ponto o esquema do herói proposto por Joseph Campbell (1995) mostra a sua universalidade, já que a viagem é condição sine qua non para a aventura heroica. Para Marcel Brion (1977, p. 7),

\begin{abstract}
toda viagem, quer se realize no tempo ou no espaço, quer reconduza o indivíduo ao nível mais profundo de si próprio ou represente magistralmente as mudanças mais espetaculares, é, de muitas e diferentes maneiras, uma iniciação. O progresso da vida, este "progresso do peregrino" que ensina o homem sobre a natureza do universo e sobre sua própria natureza, que o conduz ao centro de seu ser, ou o projeta para todos os pontos circunferentes de seu devir, acrescenta conhecimento e experiência, modifica e metamorfoseia. Até mesmo os périplos através dos arquipélagos da sátira, as ilhas de Swift e as cidades subterrâneas de Holberg, informam laboriosamente ao viajante as causas de suas tempestades íntimas e lhes mostram através dos filtros amargos do desencanto e da ironia as tentativas pouco encorajadoras de 'toda natureza humana' e as amargas conquistas do espírito.
\end{abstract}

Walter Benjamin elenca dois tipos de narradores: o viajante e o sedentário. 0 narrador de Parsifal pertence ao primeiro grupo. Benjamin (2010, p. 198) diz que "a experiência que passa de pessoa a pessoa é a fonte a que recorreram todos os narradores" e é exatamente isso que Wolfram fez ao narrar a história do herói do Graal.

O narrador de Parsifal faz com que o leitor viaje com ele e seu herói, visto que "o narrar é a aventura errante, a que as vozes se entregam, no afã de encontrar o próprio lugar no mundo" (GOMES, 1991, p. 123). Que voz é essa? É a do grande narrador, aquele que tem suas origens no povo, que adquiriu a sua técnica na oralidade e comunicabilidade de suas palavras, sejam elas faladas ou escritas. Wolfram tem uma consciência narrativa e poética espantosa para a sua época. Não pode ser esquecido o fato de que se está falando de um autor do século XIII, quando os romances ainda eram escritos em versos e os mecanismos de narração estavam em formação. Aqui não só o que se conta é importante, mas o como se conta. Cabe aqui relembrar a diferença entre romances de cavalaria e novelas de cavalaria. Os primeiros foram escritos em verso, no século XII e início do XIII, já as novelas foram escritas em prosa do segundo quartel do século XIII em diante.

O narrador conversa com o leitor sobre a sua história e expõe seu processo de 
composição. Eis um excerto exemplificativo desse procedimento:

É nesse momento que começa a narrativa propriamente dita, pois somente agora nascia aquele a quem este relato diz respeito. Até aqui ouvistes umas tantas coisas acerca da boa e má fortuna do pai, sobre sua vida e sua morte. Agora que conheceis a origem do herói desta história, dar-vos-ei igualmente notícia sobre a forma pela qual era protegido. Foi-me dito que desde a infância ele era mantido afastado de qualquer atividade própria de um cavaleiro. (ESCHENBACH, 1995, p. 91).

Ele dirige-se ao leitor e o informa a respeito da estrutura narrativa, do mesmo modo como diz que soube da história por um terceiro, que, por enquanto, permanece anônimo. A maioria dos romances e novelas de cavalaria remete a um livro anterior, isto é, o narrador recebeu de alguém a sua história. Essa idéia levou Ítalo Calvino (1995, p. 63) a supor que a própria cavalaria "não tenha nunca existido antes dos livros de cavalaria ou até que só existiu nos livros". Sabe-se que a cavalaria existiu de fato, mas metaforicamente Calvino quis dizer que a cavalaria conhecida por todos nós é a literária, isto é, a idealização imaginária daquela cavalaria real.

No momento adequado, o narrador nomeia a fonte da sua história: "foi Kyot quem me pediu que mantivesse esse assunto em segredo até que a narrativa se aproximasse do ponto onde a revelação se impusesse". (ESCHENBACH, 1995, p. 291) Kyot, o Provençal, encontrou o original da história e a traduziu da língua pagã. Contudo, o verdadeiro narrador é Wolfram, pois não se tem conhecimento da história de Kyot, exceto pelo narrador de Parsifal. Percebe-se que o narrador sabe manter o suspense, dando as informações necessárias aos poucos.

Esse narrador intromete-se na história diversas vezes, quer para dar sua opinião, usando expressões como: "eu deduzo" (ESCHENBACH, 1995, p. 101), "eu não estaria em meu juízo perfeito" (ESCHENBACH, 1995, p. 135), "mas não estou sendo coerente" (ESCHENBACH, 1995, p. 457), quer para ser irônico "domino razoavelmente a arte da composição poética" (ESCHENBACH, 1995, p. 92), "é que não sei ler nem escrever" (ESCHENBACH, 1995, p. 93). Ao longo da história, o narrador fala sobre si mesmo e ao tomar consciência do que está fazendo, espantase: "mas eis-me falando sobre mim mesmo" (ESCHENBACH, 1995, p. 151); em outro momento diz: "Mas agora chega! Já me queixei demais." (ESCHENBACH, 1995, p. 135)

Do mesmo modo, o narrador dialoga com o leitor sobre o próprio ato de narrar, 
por meio de perguntas diretas e indiretas, fazendo com que o seu interlocutor preste muita atenção e fique curioso para saber o que acontecerá em seguida, principalmente em passagens como: "quem estiver desejoso de saber para onde Parsifal seria impelido por sua sede de aventuras ouvirá, sem demora, coisas extraordinárias" (ESCHENBACH, 1995, p. 159) ou "quereis agora conhecer os motivos que levaram Artur a acolher o conselho de seus nobres e deixar seu país e seu castelo em Karidoel" (ESCHENBACH, 1995, p. 191). Esse artifício de perguntar e responder as suas próprias perguntas é herança da narrativa oral. Não nos esqueçamos de que esses romances eram lidos na corte para os nobres. Wolfram provavelmente tinha ciência de que "quem escuta uma história está em companhia do narrador" (BENJAMIN, 2010, p.213). O narrador de Parsifal nos diz de que forma recebeu a sua narrativa de outra pessoa: "Foi Kyot quem me pediu que mantivesse esse assunto em segredo, [...] Kyot, o renomado mestre, encontrou em Toledo, num manuscrito pagão, o original desta narrativa, que havia sido posto de lado como coisa sem valor" (ESCHENBACH, 1995, p. 291).

Ao final da história, o narrador alemão repreende o narrador francês, que contou a história de Perceval antes dele, pois "Mestre Chrétien de Troyes não se mostrou muito fiel ao contar a mesma história" (ESCHENBACH, 1995, p. 495). Wolfram antecipou em, pelo menos, 400 anos procedimentos ficcionais dos primeiros romances - Robinson Crusoe, Viagens de Gulliver - e dos romances românticos que se utilizavam de recursos semelhantes para legitimarem a narração, baseando-a em acontecimentos reais.

Chrétien também é um habilidoso narrador, mas não concluiu a sua história. $\mathrm{Na}$ parte da narração atribuída a ele, podemos perceber o mesmo narrador popular, porém sem a grande habilidade de Wolfram. Chrétien de Troyes fala que recebeu o tema do Graal de um livro de Felipe de Flanders. Ao longo de sua narrativa, utiliza recursos como: "diz o conto" (TROYES, 1992, p. 34), referindo-se a sua fonte. Em outros momentos, para não repetir a narração, usa fórmulas como: "seria ocioso repetir a narração" (TROYES, 1992, p. 43), "não é possível narrar todos os golpes um por um" (TROYES, 1992, p. 53) e "Se me desse ao trabalho, poderia narrar os episódios; mas de que serviria?" (TROYES, 1992, p. 59). Chrétien também sabe como antecipar a narrativa e manter o suspense: "Temo que as cousas desandem, pois aconteceu-me ouvir que calar demasiado nem sempre é melhor que falar demasiado. Assim, quer isso traga astres ou desastres, o hóspede não faz uma só 
pergunta." (TROYES, 1992, p. 67).

Por um lado, não se tem o narrador de Benjamin na Demanda, pois o seu caráter é mais didático do que narrativo. Ainda que, em alguns momentos, pareça que o narrador vai realmente tomar conta da narração, ele volta, a seguir, ao seu papel autoritário. Por outro lado, a narrativa da Demanda iniciando in media res pressupõe que o seu leitor conheça as histórias de rei Artur e de seus cavaleiros. Em algumas partes, o narrador aproxima-se do popular, mas sem o mesmo talento dos dois anteriores.

Na Demanda, há referências a outros livros, usando as seguintes estruturas como: ora diz o conto que..., conta o conto que..., mas ora deixa o conto de falar de..., entre outras variantes. Há, também, referências à história contada por Robert de Boron que "não ousou traduzir [...] em francês de latim, porque os segredos da santa Igreja não quis ele revelar, porque não convém que os saiba homem leigo" (MEGALE, 1992, p. 68). Obviamente, a Bíblia está presente como intertexto do início da narração até a morte de Galaaz.

Observamos, na Demanda, uma intertextualidade que sempre fez parte das narrativas ficcionais e que hoje caracteriza o romance contemporâneo. Há várias passagens no texto em que aparece o diálogo com outros textos contemporâneos da Demanda. Por exemplo, com o Tristão em passagens como: "Mas isto não relata agora a estória do santo Graal, porque não toca a seu livro, mas a grande estória de dom Tristão o conto no seu livro" (MEGALE, 1992, p. 33) ou "e se alguém quer saber como levou a termo sua demanda, [...], pegue a grande estória de Tristão, pois ali poderá achar completamente a verdade de todas essas cousas" (MEGALE, 1992, p. 234) e "e quem quiser saber como amou primeiramente Isolda e quanto fez e sofreu por ela, a grande estória de tristão lhe dirá" (MEGALE, 1992, p. 289). Há, da mesma forma, referências aos textos de Boron, Merlim e Lancelote. No caso de Robert de Boron em: "mas não vos direi como, porque o não achei em francês, nem Boron diz que a respeito tenha mais achado na grande estória do latim de quanto vos conto" (MEGALE, 1992, p. 285). Em relação a Lancelote: "como a grande estória de Lancelote o conta" (MEGALE, 1992, p. 439). Nos romances sobre Merlim, ele era chamado de Brado, que é uma corruptela de bardo: "O que aqui falta das aventuras de Galaaz está no conto do Brado" (MEGALE, 1992, p. 440), "Mas sem falha, o que deixo nesta derradeira parte está no conto do Brado" (MEGALE, 1992, p. 441), "e acharam muitas aventuras que não conta aqui a estória, mas no romance do Brado 
as achareis." (MEGALE, 1992, p. 443), "pelo encanto de Merlim, assim como o conto já referiu" (MEGALE, 1992, p. 31). Contudo, na Demanda, não há essa referência anterior. Todas essas passagens no texto referem-se a outros textos, atestando a tripartição de um texto original ou a continuidade de um ciclo.

O bom narrador, e aqui se falou dele, faz com que o seu leitor viaje com ele. Ainda que na Demanda o narrador não seja tão popular como os dois anteriores, viajamos também com ele. Entretanto, devemos salientar que os dois autores tinham contato com os narradores populares e ouviram outras histórias deles, aprendendo talvez com esses narradores algumas técnicas, que os dois aperfeiçoaram. Grande parte dos romances e novelas de cavalaria tem afinidades com a viagem iniciática, por isso Marcel Brion (1977, p. 13-14) salienta que

\begin{abstract}
viagem iniciática e romance de formação, ou romance de experiências (Bildungsroman, Erlebnisroman) seguem caminhos paralelos com orientações e inflexões diversificadas, segundo a urgência do deslocamento, sua direção e seus motivos. Quer seja mística ou utilitária, a viagem se organiza diferentemente, dependendo se seu trajeto for uma simples ida, em linha reta ou ziguezagueante conforme os encontros, ou circular terminando necessariamente pela volta para sua casa. Quando o princípio da busca predomina, o Velocino de ouro, o Graal, parece que, uma vez atingido o fim, a necessidade material ou espiritual satisfeita que ocasionou o elemento matriz, o movimento para: o itinerário de volta não é importante e não merece ser descrito.
\end{abstract}

Por esse motivo, Galaaz e Perceval não querem voltar a Logres, após a conquista do Graal: não há mais nada importante a ser feito. A busca foi completada.

\title{
3 OS PERSONAGENS: TIPO VERSUS SÍMBOLO
}

Nesses romances, os protagonistas devem demonstrar o seu valor perante a sociedade (entenda-se aqui aquela sociedade cortês idealizada nos romances), saindo em busca de aventuras, quer por amor, quer por glória pessoal. O cavaleiro deve ser testado ao máximo para avaliar as suas qualidades. Ao contrário de Lancelot, Tristão e seus amores adúlteros, Galaaz e sua predestinação, Perceval será o protótipo do herói das últimas novelas de cavalaria: Tirant, Amadis, Palmeirim e até Dom Quixote; afinal "muitos são os protagonistas que abandonam o mundo em que vivem, em busca de novas experiências, de forma a criarem uma identidade própria e original”. (LOPES, 1997, p.467) Se, por um lado Perceval obtém essa identidade pelo seu percurso, por outro, não há crescimento em Galaaz, ele é o 
eleito desde o início. Não há aprendizagem em seu percurso ao longo da Demanda, tudo já estava previsto: desde a sua aparição até a realização das maravilhas do reino de Logres.

Em relação ao cavaleiro, este sempre é educado por alguém de fora da família, o que era uma prática comum entre a aristocracia, demonstrando que o cavaleiro é um nobre ou, pelo menos, possui hábitos de nobre. Perceval foi educado por Gurnemanz, e Galaaz, num mosteiro, como veremos nos capítulos referentes a cada um dos heróis.

Nos dois primeiros textos o herói do Graal é Perceval, um homem comum que deve merecer o Graal pelo seu esforço e dedicação. Ele deve superar duras provas: derrotar bravos e valentes cavaleiros, salvar donzelas e, acima de tudo, ter paciência para aguentar cinco anos até estar pronto para voltar ao castelo do Graal. O outro herói nos dois primeiros textos aqui estudados é Galvão, mas a sua preocupação é mais cortês e, portanto, mais coletiva do que individual. Assim sendo, ele não está nem quer ficar preparado para o Graal. Perceval deseja o Graal acima de tudo e fará de tudo para obtê-lo.

Na Demanda o herói principal, Galaaz, é um ser semidivino. Ele possui qualidades ímpares: pode curar pessoas, espantar demônios, entrar em locais misteriosamente, mas, acima de tudo, é um novo Cristo: veio redimir a sociedade cortês. Os outros dois heróis, Boorz e Perceval, são piedosos, humildes, assemelhando-se, dessa forma, mais a monges do que a cavaleiros. Outra diferença a ser ressaltada é o poder de escolha do herói. Em Chrétien e Wolfram, Perceval pode mudar o seu destino e alcançar o Graal por merecimento. Na Demanda, Galaaz é destinado ao Graal e nada pode impedi-lo de chegar até lá.

Os vilões nos dois primeiros textos são cavaleiros que reconhecem o valor do seu vencedor: Perceval. Todos que são derrotados por ele veem nele o espelho da cavalaria, reconhecendo o valor dele: forte, bravo, honrado. Na Demanda, os maus cavaleiros são invejosos, pecadores, traidores.

Antonio Prieto elenca dois tipos de personagens: tipo e símbolo. O primeiro tipo seria aquele personagem que "sofre com o tempo um desgaste de sua realidade que pode levá-lo a ser entendido como irreal (e incompreendido) por leitores que vivem muito tempo depois da época em que o emissor compôs a obra." (PRIETO, 1975, p. 46) $O$ segundo, 
a personagem símbolo busca (de modo análogo à personagem de fusão mítica) sua formação em constantes humanas que, direta ou indiretamente, a levam a vencer os incidentes da cronologia do emissor para situá-la em qualquer tempo (e frequentemente lugar). (PRIETO, 1975, p. 46).

Notamos nos romances aqui estudados que esses dois tipos de personagens estão presentes. Na Demanda, todas as personagens são tipificadas. Todas elas sofreram um desgaste com o tempo. Ao passo que em Chrétien e Wolfram, Perceval é uma personagem símbolo, pois o leitor moderno pode identificar-se com a personagem.

\section{CONSIDERAÇÕES FINAIS}

O romance de cavalaria puro, como o de Wolfram von Eschenbach, teve a sua pluralidade de vozes silenciada e transformada numa única voz ao ser transformado em prosa e ao ter sido utilizado pela Igreja. O discurso do herói é contra a ordem imposta; mesmo que Deus não esteja ao seu lado, ele procura seu próprio caminho. No final, ainda que arrependido do que fez, ele não se tornou um católico, aceitando todas as imposições da Igreja, nem um cortês, aceitando as imposições da corte, mas venceu por conta própria e continuou autêntico e fiel a sua ideologia. Perceval está muito mais próximo do cristianismo primitivo, da heresia e antecipa, em quase três séculos, o Luteranismo. Ele já utiliza o conceito de livre-arbítrio, isto é, "a sua capacidade para forjar seu destino de acordo com o valor possuído, o esforço despendido e o respeito dedicado às leis universais" (FRANCO JÚNIOR, 1999, p. 177).

Para Bakhtin (2010), há uma utilidade nos romances de cavalaria: ensinar certas regras, como Hauser (2010) também assinalou. Nós acrescentaríamos ainda que $\mathrm{o}$ romance de cavalaria visava domesticar a cavalaria verdadeira. A domesticação da cavalaria ocorre a partir do século XI com a criação das ordens religioso-militares, com o intuito de controlar. Contudo, com a cristianização desses romances, o objetivo passou a ser outro: ensinar um comportamento cristão ideal.

Em Wolfram, temos um diálogo com todas as ideologias da época. Ele, como nenhum outro escritor da Idade Média, soube captar e transferir para o seu romance os conflitos de sua época. Cada personagem tem um discurso diferente. Além disso, Wolfram é um narrador popular, como vários que Benjamim admirava. Wolfram foi 
um grande escritor, pois possuía uma consciência do fazer literário e narrativo que demoraria três séculos até que surgisse outro grande narrador como ele, nesse caso, Rabelais. Um século após o escritor francês, Cervantes parodia o romance de cavalaria como um todo. Na verdade, concordamos com Mario Vargas Llosa (1998) ao considerar o Dom Quixote uma homenagem aos romances de cavalaria da única forma que Cervantes poderia ter feito: parodiando. Wolfram soube como usar a linguagem, como cativar seu público, como ser irônico, sarcástico. Isso fez com que ele, direta ou indiretamente, influenciasse todos os grandes humoristas, pois Cervantes, que foi influenciado por ele, influenciou escritores como Sterne, Swift, entre outros. Há muito de Wolfram em Dom Quixote, mas a nossa tarefa aqui não é comparar Wolfram e Cervantes. Também Wolfram influenciou todos os romances de educação ou formação, que têm nele o modelo. Bakhtin (2010) soube reconhecer em Wolfram algumas qualidades, porém não as demonstrou detalhadamente. Essa pluralidade de vozes e influências não pode ser percebida no texto português da Demanda.

O texto português apresenta uma uniformidade e um dualismo muito claro: bem versus mal. Galaaz, Perceval e Boorz em várias passagens são muito parecidos. Aliás, a apropriação feita dos heróis transformou vários personagens símbolos, tais como Perceval, Lancelote, Tristão e Galvão em personagens tipo. Ao cristianizar os romances, a Igreja tenta impor um controle sobre o que pode ou não ser lido. A Igreja vê na literatura uma função pedagógica e talvez por esse motivo tenta usá-la como elemento propagador de suas ideias e crenças.

\section{NOTA}

1 Doutor em Letras pela PUCRS. Professor Adjunto 2 de Teoria Literária e Literaturas de Língua Portuguesa na Universidade Federal da Fronteira Sul - Campus Cerro Largo - RS. 


\section{REFERÊNCIAS}

AUERBACH, Erich. Mimesis: a representação da realidade na literatura ocidental. 4. ed. São Paulo: Perspectiva, 2002. . Introdução aos estudos literários. São Paulo: Cultrix, 1989.

BAKHTIN, Mikhail. Questões de literatura e de estética: a teoria do romance. São Paulo: Hucitec, 2010.

BENJAMIN, Walter. O narrador: considerações sobre a obra de Nikolai Leskov In: . Magia e técnica, arte e política: ensaios sobre literatura e história da cultura. 12. ed. São Paulo: Brasiliense, 2010. Obras Escolhidas I.

BRION, Marcel. L'Allemagne romantique: le voyage initiatique I. Paris: Albin Michel, 1977.

CALVINO, Ítalo. Por que ler os clássicos. São Paulo: Companhia das Letras, 1995.

CAMPBELL, Joseph. O herói de mil faces. 4. ed. São Paulo: Cultrix/Pensamento, 1995.

CARPEAUX, Otto Maria. A Literatura alemã. São Paulo: Nova Alexandria, 1994.

. História da literatura ocidental. Rio de Janeiro: Alhambra, 1978.

CORP, Hendrik van et al. Dictionnaire des tremes littéraires. Paris: Honoré Champion, 2001.

Danielle Régnier-Bohler. Amor cortesão. In: LE GOFF, J.; SCHIMITT, J. Dicionário temático do Ocidente medieval. Bauru: EDUSC, 2002. p. 48. v. 1.

DUBY, Georges. As damas do século XII. São Paulo: Companhia das Letras, 2013. . Idade Média, Idade dos Homens: do amor e outros ensaios. São Paulo: Companhia das Letras, 1998.

ESCHENBACH, Wolfram von. Parsifal. São Paulo: Antroposófica, 1995.

FERREIRA, Maria Ema Tarracha. Poesia e prosa medievais. 2. ed. Lisboa: Ulisséia, 1988.

FRANCO JÚNIOR, Hilário. A Idade Média: nascimento do Ocidente. São Paulo: Brasiliense, 1999.

. História, literatura e imaginário: um jogo especular. O exemplo medieval da cocanha. In: IANONE, Carlos Alberto et al. Sobre as naus da iniciação: estudos portugueses de literatura e história. São Paulo: UNESP, 1998.

GOMES, Álvaro Cardoso. A voz itinerante. São Paulo: EDUSP, 1991. 
HAUSER, Ernest. História social da arte e da literatura. São Paulo: Martins Fontes, 2000.

LAPA, Manuel Rodrigues. Lições de literatura portuguesa: era medieval. Coimbra: Coimbra, 1966.

LE GOFF, Jacques (Org.). Homens e mulheres da Idade Média. São Paulo: Estação Liberdade, 2013.

LLOSA, Mario Vargas. Tirant lo blanc: as palavras como atos. In: MARTORELL, Joanot. Tirant lo blanc. São Paulo: Giordano, 1998. nov. 1984.

A mentira e a verdade na ficção. O Estado de São Paulo, São Paulo, 18

LOPES, Ana Maria Costa. A viagem no conto popular português. In: FALCÃO, A. M.; NASCIMENTO, M. T.; LEAL, M. L. (Org.). Literatura de viagem: narrativa, história, mito. Lisboa: Cosmos, 1997.

MEGALE, Heitor. A Demanda do Santo Graal. Versão para o português moderno de Heitor Megale. São Paulo: T.A.Queiroz, 1992.

PRIETO, Antonio. Morfologia de la novela. Barcelona: Planeta, 1975.

SCHOLES, R.; KELLOGG, R. A Natureza da narrativa. São Paulo: McGraw-Hill, 1977.

SPINA, Segismundo. A Cultura literária medieval. São Paulo: Ateliê Editorial, 1997. A lírica trovadoresca. São Paulo: Edusp, 1996.

TROYES, Chrétien de. Perceval ou o romance do Graal. São Paulo: Martins Fontes, 1992.

. Romances da Távola Redonda. São Paulo: Martins Fontes, 1998.

VILHENA, Maria da Conceição. Literatura francesa medieval. Lisboa: Universidade Aberta, 1990.

WILLEMART, Philippe. A Idade Média e a Renascença na literatura francesa. São Paulo: Annablume, 2000.

ZUMTHOR, Paul. A letra e a voz. São Paulo: Companhia das Letras, 2001. 